\title{
The Economics of Irrigation in Almond Orchards. Application to Southern Spain
}

\author{
Alfonso Expósito ${ }^{1, *(1)}$ and Julio Berbel ${ }^{2}$ (i) \\ 1 Department of Economic Analysis and Political Economy \& WEARE, University of Seville, \\ 41004 Sevilla, Spain \\ 2 Department of Agricultural Economics \& WEARE, University of Cordoba, 14071 Cordoba, Spain; \\ berbel@uco.es \\ * Correspondence: aexposito@us.es; Tel.: +34-656626953
}

Received: 22 April 2020; Accepted: 1 June 2020; Published: 3 June 2020

\begin{abstract}
This paper offers an exploratory microeconomic analysis of water use in the cultivation of almonds when water is considered a limiting production factor. When a crop is subjected to water limitation, the microeconomic principles behind irrigation decisions are based upon the water-yield relationship. The analysis is applied to an estimated water-yield response function for irrigated almond trees in southern Spain; our research focuses on determining the optimal irrigation dose when deficit irrigation is applied, as it is usual in water-scarce contexts. The situation in Spain is compared to that of other countries where water rights are less constrained. The economic analysis of the water production function is crucial, since it determines farmers' income and helps them make appropriate management decisions, such as simultaneous decisions regarding the allocation of limited water to crops and the size of the irrigated area for almond production. Furthermore, public institutions need this basic information for the allocation of water in times of increasing water demand and of limited and decreasing resources.
\end{abstract}

Keywords: water-yield response function; deficit irrigation; water-limiting condition; almond crop

\section{Introduction}

Water-yield response functions under water-availability limitations have been widely analysed in the literature with two essential objectives: a) determination of a functional response between yield and water use and $b$ ) analysis of the role played by different irrigation regimes in transpiration efficiency and water productivity. Research into water-yield response functions started with maize by Stewart and Hagan [1], although interest from economists began later with the use of production functions to optimize water usage and to maximise revenue [2-4]. Crops cultivated in arid or semiarid regions of the world have attracted more attention. Moriana et al. [5] offered a quadratic water-yield response function for traditional olive groves, and Mesa-Jurado et al. [6] estimated the value of water in olive irrigation based on this same agronomic estimated response.

The present research applies the microeconomic theory of production to the study of the behaviour of farmers who have to make decisions regarding the allocation of scarce production resources, such as the extent of irrigated land and water allocated per hectare. Following a similar microeconomic approach, Expósito and Berbel [7] derived a water-response function under a scheme of deficit irrigation in olive groves and analysed farmers' perception and choice regarding the optimal irrigation dose.

Similarly, the case of almond trees has also attracted significant attention. The impact of water deficits on almond production has been studied by Goldhamer and Viveros [8], by Goldhamer et al. [9], and by Esparza et al. [10] in the case of California; by Girona et al. [11] and by Egea et al. [12] in Spain; and by Stevens et al. [13] for Australia. More recently, the study by Goldhamer and Fereres [14] 
has offered an estimation of a water-yield response function in the case of California where water is a limiting factor and the study by López-López et al. [15] applied a similar analysis in the case of southern Spain. However, none of the studies offers a microeconomic analysis of the optimal allocation of water based on a contrasted economic model. A similar application of the microeconomic analysis carried out in this work can be found in Expósito and Berbel [7], who extended and empirically tested the models of English [16] and of Berbel and Mateos [17] for the case of deficit irrigation in olive groves located in southern Spain. In order to apply the proposed microeconomic analysis to irrigated almond crops, the water-yield response function estimated by López-López et al. [15] in the case of southern Spain is applied in this work and several comments on the information available on Australia and California are then made in the Discussion section.

In a context of increasing water scarcity for irrigation purposes, policy makers and water administrators as well as almond farmers need to understand the microeconomic principles behind irrigation decisions in order to be able to accurately assess economic returns and to evaluate future business risks. These principles remain unknown in the case of almond crops, and this study aims to fill this gap.

The selection of southern Spain as the case study is justified since the high water consumption related to the irrigation of almond trees has become controversial due to increasing water scarcity, especially in the southern and eastern regions of Spain. Moreover, the increasing frequency and length of drought periods due to climate change pose significant challenges to water management in Spain. When a crop is subjected to water limitation, the water-yield response function should guide the microeconomic principles behind the irrigation decisions. This knowledge is crucial, since it determines the farmers' income and helps them make appropriate management decisions (such as allocating limited water to various crops). Furthermore, water authorities and public administrations need this basic information in order to assign water allocation in a context of increasing demand and limited resources.

The structure of the paper is as follows. Section 2 briefly presents the microeconomic foundations of the model used in this study. Section 3 gives a brief description of the case study and of the cultivation of irrigated almonds in southern Spain under a deficit-irrigation scheme. The results are shown in Section 4, followed by a brief discussion and concluding remarks in Section 5 .

\section{Methodological Approach}

The analysis of crop yield and water use to improve water management was initially proposed by Doorenbos and Kassam [18]. The extensive literature that examines the water-response functions covers a wide variety of crops $[19,20]$. Empirical and theoretical yield-irrigation functions are usually deduced from longitudinal field data and are based on estimated agronomic coefficients. Specifically, a recently estimated yield-irrigation function for almond trees for southern Spain [15] is used in this study. Commonly, yield-irrigation functions are used to obtain derived water-demand functions defined by the marginal value of irrigation water. By applying the production function $y(w)$, marginal productivity of irrigation water $(w)$ can be obtained from its partial derivative with respect to water " $w$ ". The marginal value of irrigation water is thus obtained from the crop price multiplied by the estimated marginal productivity.

In our model, farmers with rational economic behaviour should maximise the following profit equation by taking land as the single limiting factor and water as the variable:

$$
Z=p_{y} \cdot y(w)-c(w)
$$

where $\mathrm{Z}$ represents profit, $p_{y}$ is crop price, $y(w)$ is the water-yield function, and $c(w)$ is the function of water cost. Farmers are assumed to hold a price-taking position (they cannot influence crop price with their individual production). Berbel and Mateos [17] expanded the model originally developed by English [16] by including deficit irrigation and changes in irrigation efficiency. Therefore, water can be 
shared across a larger area and Equation (1) is transformed into Equation (2), where the objective is to maximise total net income by distributing both the irrigated area and the water dose.

$$
Z(w)=\left[p_{y} \cdot y(w)-c(w)\right] \cdot A
$$

Equation (2) considers that the irrigated area $(A)$ is variable in the optimisation model, and the farmer decides the allocation of water " $w$ " per area unit for maximising net income. The total volume of water $\left(W_{T}\right)$ acts as the limiting factor and determines the irrigated area:

$$
A=\frac{W_{T}}{w}
$$

Thus, by satisfying Equation (1), the optimal water allocation per area unit is then defined by the value of $w$ that optimizes Equation (2) subject to Equation (3).

$$
-A \times \frac{\partial Z(w)}{\partial w}=Z(w) \times \frac{\partial A}{\partial w}
$$

It is frequent to find quadratic water-yield response functions in the agronomic literature, and by following Reference [3], we use $y(w)$ and a cost function $c(w)$ composed of a fixed cost $\left(c_{f}\right)$ and a variable water $\operatorname{cost}\left(c_{w}\right)$ as follows:

$$
\begin{gathered}
y(w)=a_{0}+a_{1} w+a_{2} w^{2} \\
c(w)=c_{f}+c_{w} w
\end{gathered}
$$

If the proposed optimisation model was applied to the above functions, then one possible solution would be based on the conventional assumption that considers land (or irrigated area) as a limiting production factor (with water as a variable factor). This solution is denoted as the "maximum return to land" equilibrium $\left(\mathrm{W}_{\mathrm{l}}\right)$ and the solution is straightforward:

$$
W_{l}=\frac{c_{w}-P_{y} \cdot a_{1}}{2 P_{y} \cdot a_{2}}
$$

In the case of a quadratic production function, the optimal solution to Equation (4) implies the following:

$$
\mathrm{Z}(\mathrm{w})=\left[\mathrm{p}_{\mathrm{y}}\left(\mathrm{a}_{0}+\mathrm{a}_{1} \mathrm{w}+\mathrm{a}_{2} \mathrm{w}^{2}\right)-\left(\mathrm{c}_{\mathrm{f}}+\mathrm{c}_{\mathrm{w}} \mathrm{w}\right)\right] \frac{\mathrm{W}_{\mathrm{T}}}{\mathrm{w}}=\mathrm{W}_{\mathrm{T}}\left[\frac{\mathrm{p}_{\mathrm{y}} \cdot \mathrm{a}_{0}}{\mathrm{w}}+\mathrm{p}_{\mathrm{y}} \cdot \mathrm{a}_{1}+\mathrm{p}_{\mathrm{y}} \cdot \mathrm{a}_{2} \mathrm{w}-\frac{\mathrm{c}_{\mathrm{f}}}{\mathrm{w}}-\mathrm{c}_{\mathrm{w}}\right]
$$

By setting the derivative to zero, the level of " $w$ " that maximises overall profit can be obtained from the following:

$$
\frac{\partial Z(w)}{\partial w}=W_{T}\left[\frac{-p_{y} \cdot a_{0}}{w^{2}}+p_{y} \cdot a_{2}+\frac{c_{f}}{w^{2}}\right]=0
$$

Hence, the solution denoted as the "maximum return to water" equilibrium $\left(W_{w}\right)$ can be expressed by the following:

$$
W_{w}=\left(\frac{P_{y} \cdot a_{o}-c_{f}}{P_{y} \cdot a_{2}}\right)^{1 / 2}
$$

Finally, farmers may be interested in the maximum achievable yield per area, which can be computed when the marginal product equals zero. This solution is widely used in the field of agronomics to determine the maximum irrigation requirements. In our proposed model, the maximum yield point is achieved at the value represented by $W_{y}$ :

$$
W_{y}=\frac{-b_{1}}{2 c_{1}}
$$


Although this last solution is relevant for agronomic analysis, from an economic point of view, it requires that the marginal cost of water equals zero. This solution is only useful under the condition that the maximisation of total food production is the priority. English [2] included all variable costs that can be linked to yield (fertilizer, harvesting, etc.) in the price of irrigation water $\left(c_{w}\right)$. In our model, all inputs except water are included in the parameter of fixed costs.

\section{Case Study}

Spain is the third greatest almond-producing country in the world, after Australia and USA, and represents $5 \%$ of total world production, with a productive area of about 560,000 ha and an annual average production of $63,600 \mathrm{Mg}$ [21]. Although most of the area is devoted to traditional rainfed production that is mainly located in the southern and eastern regions, new intensified plantations of almond groves have been put into production which use high-efficiency irrigation methods and obtain higher crop productivities. This has led to an increase of $24.8 \%$ in the cultivated area and of $73.2 \%$ in production during the period 2014-2018 [22]. The average productivity of almond groves is significantly higher in the case of irrigated crops: $1600-1800 \mathrm{~kg} / \mathrm{ha}$ vs. $400 \mathrm{~kg} / \mathrm{ha}$ for rainfed crops [22]. Deficit-irrigation techniques are used in order to maximise irrigated cultivated area in a context of limited water resources [23].

This study uses the water-yield response function developed by López-López et al. [15] based on an agronomic experiment carried out in Cordoba (southern Spain) in the period 2014-16. This location enjoys a typical Mediterranean climate, with hot and dry summers, mild winters, and an average annual rainfall of around $590 \mathrm{~mm}$. These climate characteristics are shared across the whole Guadalquivir river basin, where the experiment was located. This river basin registers increasing variability in its rainfall as well as periodic and persistent periods of drought [24]. Additionally, the Guadalquivir river basin has become a closed basin, meaning that all available water resources are allocated and that no significant future augmentation in supply is expected. This context translates into increasing conflicts among alternative water users [25]. The agronomic experiment compared water-yield responses given regarding almond trees of the Guara variety under alternative irrigation schemes. Details of the experiment are extensively described in López-López et al. [15] with a quadratic production function described by Equation (12):

$$
\mathrm{Y}(w)=243+4.87 \cdot \mathrm{w}-0.0025 \cdot \mathrm{w}^{2}
$$

with a fit adjustment measured by $R^{2}=0.72(p$-value $=0.0001)$ [15]. Regarding production costs, fixed costs account for all costs associated with production factors other than that of water. According to the reviewed literature, production costs of irrigated almond groves in Spain are reported to be approximately 2000 EUR.ha ${ }^{-1}$ with a range from 1800 EUR [26,27] to 2500 EUR [28], excluding the variable water cost. In our optimisation exercise, the cost of 2000 EUR is considered, although sensitivity analysis in the range 1800-2500 EUR.ha ${ }^{-1}$ induces no serious change. Nevertheless, a sensitivity analysis of the optimal solution under deficit irrigation shows that the optimum would be stable within this range of costs. With respect to variable cost, the irrigation water price is set at 0.12 EUR per cubic metre that is estimated as a weighted average of abstraction cost according to the Spanish Ministry of Environment [29]. The cost function is represented by Equation (13):

$$
\mathrm{C}(w)=2,000+0.12 \cdot \mathrm{w}
$$

Finally, crop price $\left(p_{y}\right)$ has been set at $5.0 \mathrm{EUR} / \mathrm{kg}$. Nevertheless, due to price instabilities in the Spanish almond exchange market [30], this study carries out a sensitivity analysis that considers the variability of prices between 4 and $6 \mathrm{EUR} / \mathrm{kg}$.

\section{Results}

\subsection{Alternative Water-Use Optimum}

Application of the proposed model in the previous section offers three possible solutions. Table 1 shows these solutions together with relevant information in order to understand the economic behaviour 
analysed by the proposed optimisation model. Firstly, the solution $\left(\mathrm{W}_{\mathrm{y}}=975 \mathrm{~mm}\right)$ represents the maximum achievable yield (Equation (11)). This solution is illustrated in Figure 1 by the irrigation dose $(w)$ that yields the maximum production and, thus, the maximum value of crop production. In this case, the value of the marginal product (VMP) of irrigation water is zero (as also shown by Figure 2), and this solution may be explained either because the famer's goal is to maximise yield regardless of water cost or because the marginal cost of water for the farmer is close to zero. The average income (AI) and average profit (AP) per cubic metre of irrigation water are 13.41 and $10.16 \mathrm{EUR}$, respectively.

Table 1. Solutions to the optimisation model: $\mathrm{W}_{\mathrm{y}}$ (maximum yield), $\mathrm{W}_{\mathrm{l}}$ (maximum return to land), $\mathrm{W}_{\mathrm{w}}$ (maximum return to water).

\begin{tabular}{|c|c|c|c|c|c|c|}
\hline Solution & $\begin{array}{c}\text { Irrigation } \\
\text { Water (w) } \\
(\mathrm{mm})\end{array}$ & $\begin{array}{c}\text { Relative } \\
\text { Irrigation } \\
\text { Supply (\%) }\end{array}$ & $\begin{array}{c}\text { Irrigated Area (ha) } \\
\text { with Total Volume of } \\
\text { Water }\left(W_{T}\right)=975 \mathrm{~mm}\end{array}$ & $\begin{array}{l}\text { Value Marg. } \\
\text { Product } \\
\left(E U R / \mathrm{m}^{3}\right)\end{array}$ & $\begin{array}{c}\text { Average } \\
\text { Income } \\
\left(\mathrm{EUR} / \mathrm{m}^{3}\right)\end{array}$ & $\begin{array}{c}\text { Average } \\
\text { Profit } \\
\left(E U R / \mathrm{m}^{3}\right)\end{array}$ \\
\hline $\mathrm{W}_{\mathrm{y}}$ & 975 & $100 \%$ & 1.00 & 0.00 & 13.41 & 10.16 \\
\hline $\mathrm{W}_{1}$ & 927 & $95 \%$ & 1.05 & 1.20 & 14.07 & 10.72 \\
\hline $\mathrm{W}_{\mathrm{w}}$ & 251 & $26 \%$ & 3.88 & 18.10 & 26.05 & 16.89 \\
\hline
\end{tabular}

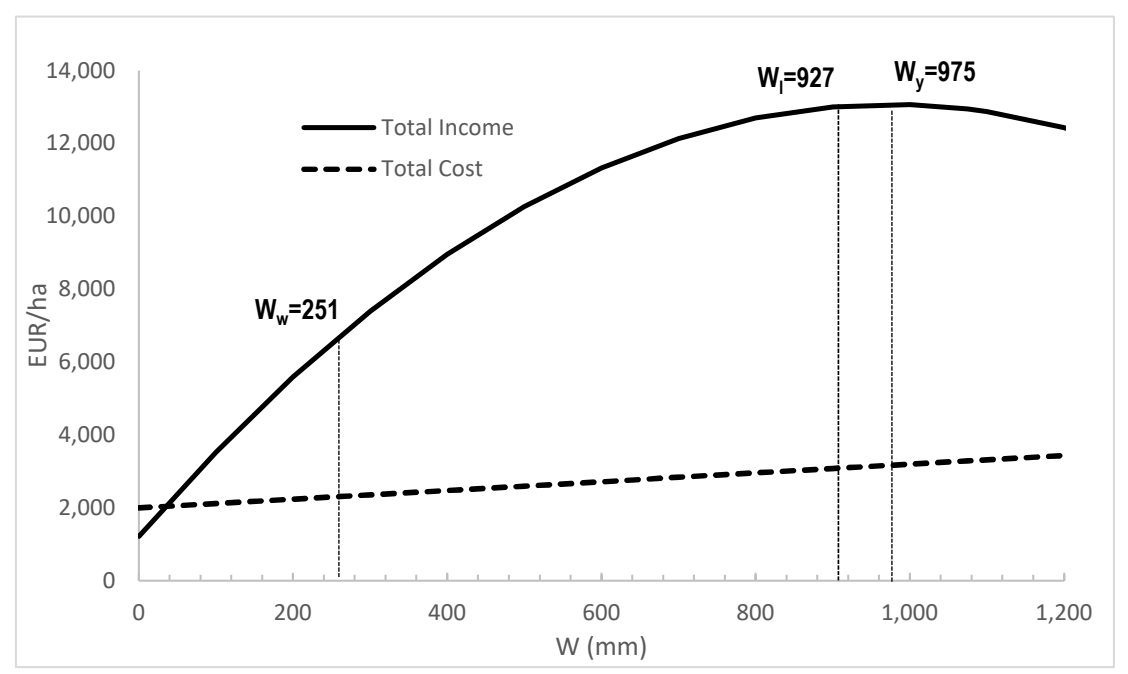

Figure 1. Graphical representation of optimisation solutions: $\mathrm{W}_{\mathrm{y}}$ (maximum yield), $\mathrm{W}_{\mathrm{l}}$ (maximum return to land), $\mathrm{W}_{\mathrm{w}}$ (maximum return to water).

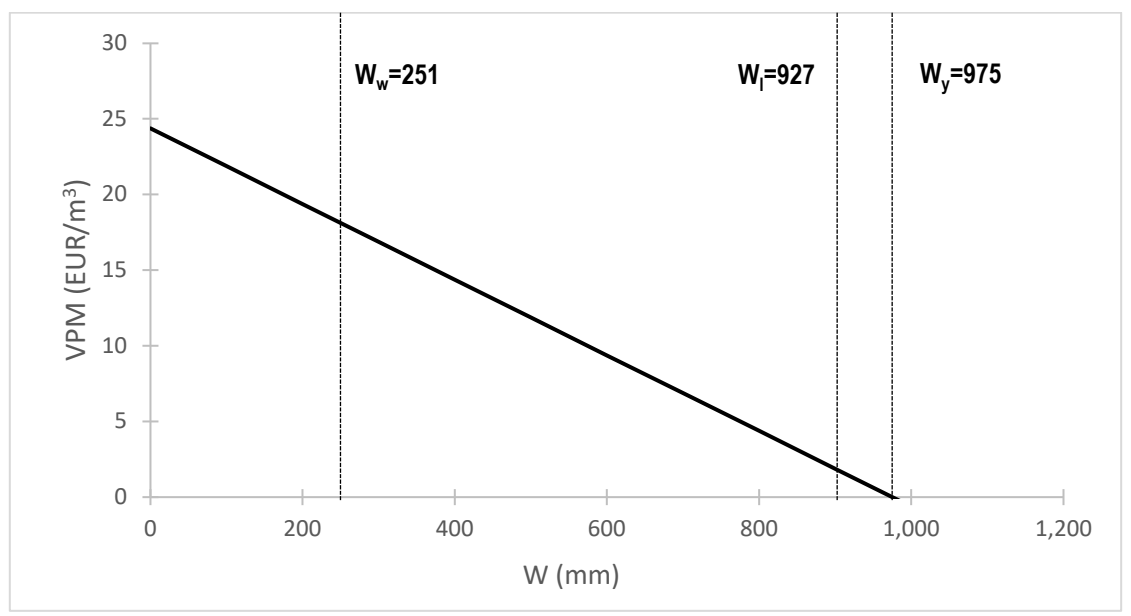

Figure 2. Value of marginal product (VMP) vs. irrigation water (W). Optimisation solutions: $\mathrm{W}_{\mathrm{y}}$ (maximum yield), $\mathrm{W}_{\mathrm{l}}$ (maximum return to land), $\mathrm{W}_{\mathrm{w}}$ (maximum return to water). 
The profit-maximising solution that corresponds to the maximum return to land $\left(\mathrm{W}_{1}=927 \mathrm{~mm}\right)$, as defined by Equation (7), requires a lower irrigation dose than does the maximum yield, which represents $95 \%$ of water use for full irrigation. In this case, the estimated VMP is $1.20 \mathrm{EUR} / \mathrm{m}^{3}$ and the $\mathrm{AI}$ and $\mathrm{AB}$ are 14.07 and $10.72 \mathrm{EUR} / \mathrm{m}^{3}$, respectively.

Finally, according to Equation (10), the maximum return to water (which assumes that water is the limiting production factor) would imply an irrigation use of $\mathrm{W}_{\mathrm{w}}=251 \mathrm{~mm}$, which is $26 \%$ of the maximum yield requirements. The estimated VMP would be $18.10 \mathrm{EUR} / \mathrm{m}^{3}$, which is significantly above the values achieved by the previous solutions. Similarly, AI and AB would be maximum values (26.05 and $16.89 \mathrm{EUR} / \mathrm{m}^{3}$, respectively, as shown in Table 1). For the sake of clarification, Figure 1 shows the graphical representation of these three optimisation solutions.

As commented above, the VMP of irrigation water decreases as the irrigation dose $(w)$ increases, since the income function grows at a decreasing rate while the cost function increases at a constant rate. This explains why the slope of the VMP function (as shown in Figure 2) is negative, and it therefore registers a zero value when maximum income (maximum yield) is reached, that is, when the irrigation dose is $\mathrm{W}_{\mathrm{y}}=975 \mathrm{~mm}$.

\subsection{Impact of Chosen Solution in Production Costs}

Figure 3 helps to describe the rational behaviour of the solution given by the maximum return to water. Specifically, an irrigation dose of $\mathrm{W}_{\mathrm{w}}=251 \mathrm{~mm}$ represents the solution where crop price (5 EUR/kg) equals the marginal cost of production (as shown by point " $\mathrm{E}$ " in the graph). This means that marginal income (crop price) equals marginal cost, which is the condition to maximise benefit for the farmer. This equilibrium point should be understood as the optimal irrigation dose to maximise the benefit by the farmer under a constrained irrigation water supply. The representation of the average crop cost function shows that the marginal cost function crosses the average cost function at its minimum value, as the microeconomic theory predicts.

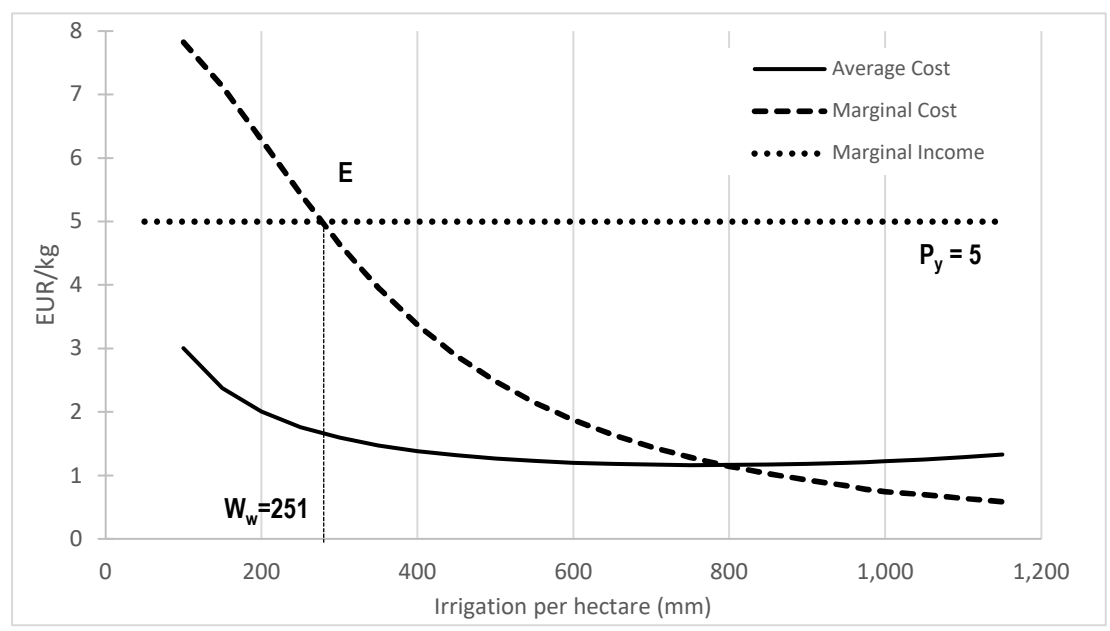

Figure 3. Graphical representation of average and marginal costs vs. water use. $W_{w}$ (maximum return to water), $\mathrm{P}_{\mathrm{y}}$ (crop price).

The economic interpretation of the $\mathrm{W}_{\mathrm{w}}$ solution (maximum return to water as the limiting factor) can also be described in terms of production cost per almond or cost of production (EUR/kg). Figure 4 illustrates the production achievable with an irrigation dose of $975 \mathrm{~mm} / \mathrm{ha}\left(\mathrm{W}_{\mathrm{y}}\right)$ when increasing the irrigated area and decreasing the irrigation dose $\left(\mathrm{w}=\mathrm{W}_{\mathrm{T}} / \mathrm{A}\right.$, see Equation (3)), which corresponds to our three optimum solutions: a) $W_{\mathrm{y}}$, maximum yield $(\mathrm{A}=1.00 \mathrm{ha}, \mathrm{w}=975 \mathrm{~mm})$; b) $\mathrm{W}_{\mathrm{l}}$, maximum return to land $(\mathrm{A}=1.05 \mathrm{ha}, \mathrm{w}=927 \mathrm{~mm})$; and $\mathrm{c}) \mathrm{W}_{\mathrm{w}}$, maximum return to water $(\mathrm{A}=3.88 \mathrm{ha}, \mathrm{w}=251 \mathrm{~mm})$. 


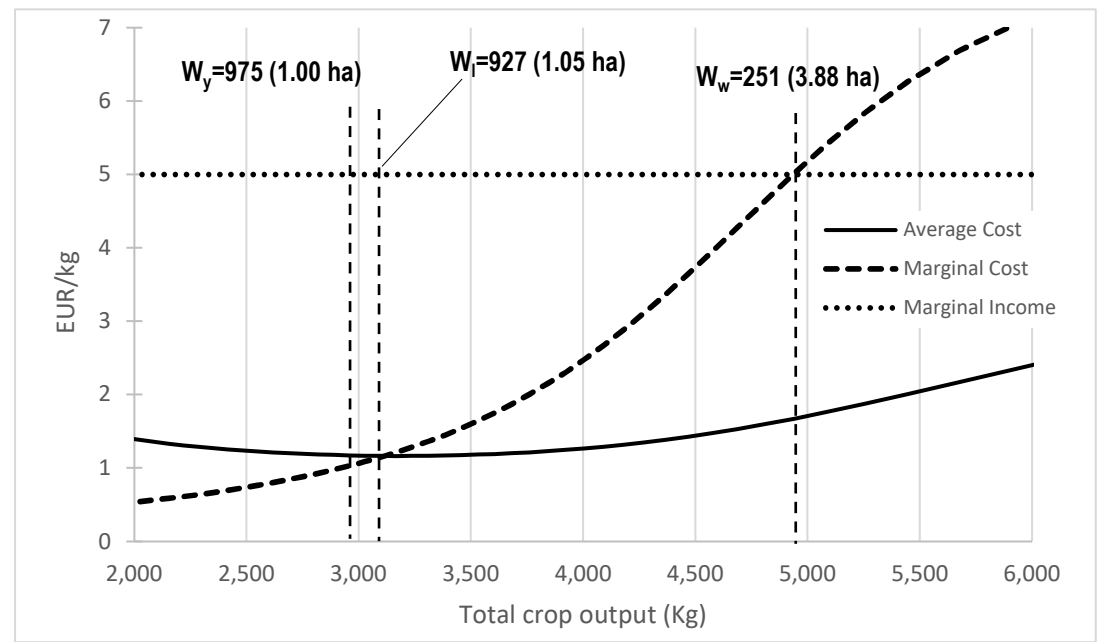

Figure 4. Graphical representation of average and marginal costs vs. total output. Optimisation solutions: $\mathrm{W}_{\mathrm{y}}$ (maximum yield), $\mathrm{W}_{\mathrm{l}}$ (maximum return to land), $\mathrm{W}_{\mathrm{w}}$ (maximum return to water).

\subsection{Sensitivity Analysis}

Both fixed costs and crop price are subject to a certain variability. Production costs depend on the characteristics of the location (e.g., terrain slope and labour cost) and of soil fertility and practices (e.g., fertilization). Revised studies offer a range of 800 to 2500 EUR per hectare. Similarly, crop price is subject to market variability. Although a certain stability in the price of the Guara variety in the Spanish market is observed, price variations are always to be considered. In order to carry out a sensitivity analysis of the results obtained with our previous exercise, Figure 5 shows the variation of the solution $\mathrm{W}_{\mathrm{w}}$ (maximum return to water under deficit irrigation) when fixed costs vary in the range 1400-3400 EUR.ha ${ }^{-1}$ for the three alternative crop prices of 4, 5, and 6 EUR/kg. As observed, the estimated variations by the estimated response functions for each crop price are not major. As an example, if fixed costs were 2000 EUR.ha ${ }^{-1}$, then solution $W_{\mathrm{w}}$ would lie in the range between $321 \mathrm{~mm}$ $\left(p_{y}=4.0 \mathrm{EUR} / \mathrm{kg}\right)$ and $190 \mathrm{~mm}\left(p_{y}=6.0 \mathrm{EUR} / \mathrm{kg}\right)$. Similarly, higher fixed costs of production lead to higher optimal irrigation doses (higher $\mathrm{W}_{\mathrm{w}}$ ), since the farmer's income should increase proportionally (and thus production and irrigation dose) in order to cope with the higher costs while maximising the average benefit of the farmer with respect to the unit of irrigation water used (as shown in Table 1).

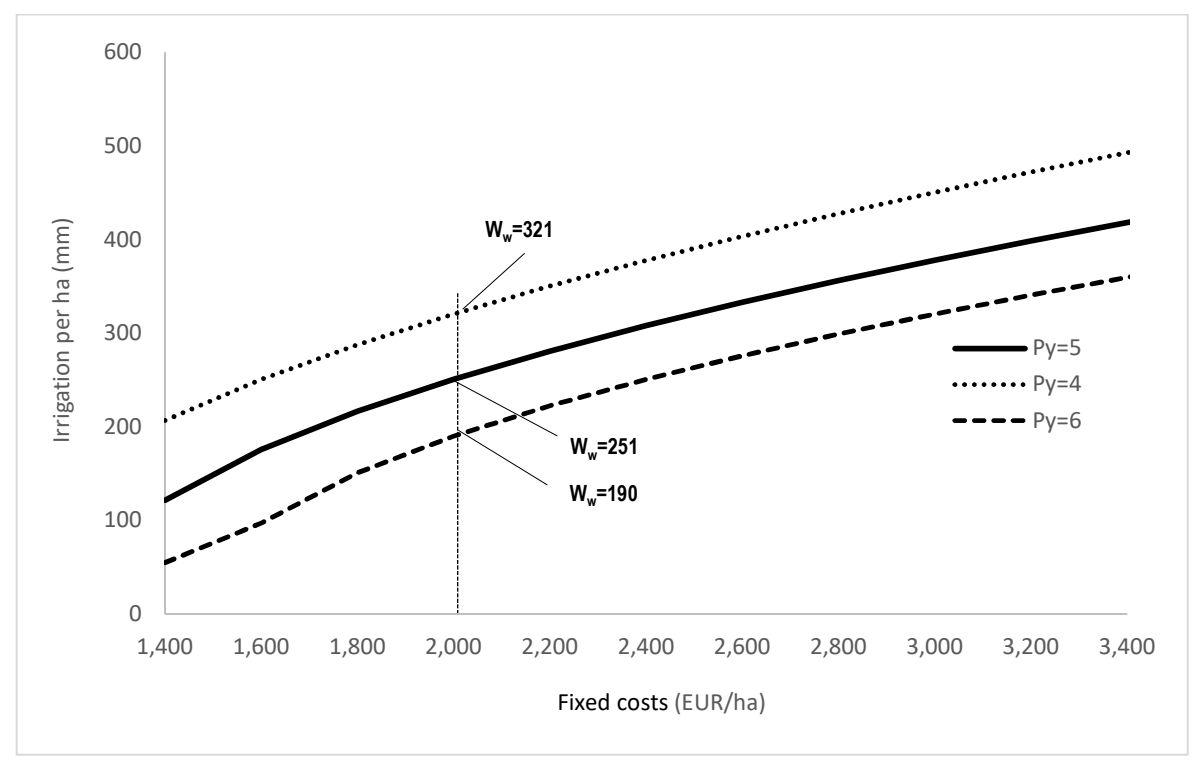

Figure 5. Sensitivity analysis of the optimum $\mathrm{W}_{\mathrm{w}}$ (maximum return to water). $\mathrm{P}_{\mathrm{y}}$ (crop price). 
The sensitivity analysis shows that optimal irrigation dose $\left(\mathrm{W}_{\mathrm{w}}\right)$ increases (irrigated area decreases) as a function of fixed costs. In contrast, the solution $\mathrm{W}_{\mathrm{w}}$ decreases (irrigated area increases) as a function of crop price.

\section{Discussion and Concluding Remarks}

This paper offers an exploratory microeconomic analysis of water use in almond groves when water is considered the limiting production factor. In this context, deficit-irrigation techniques are usually applied. The study of Molden et al. [31] argues that practices, such as deficit irrigation and precision irrigation, can significantly improve water productivity. Based on estimated water-yield response functions available in the literature [18], our research focuses on determining the optimal irrigation dose in a context of water limitation following the microeconomic model developed by English [16] and is extended by the study of English and Raja [32]. Our results offer significant implications in the field of economics of irrigation management, which are valuable for irrigators and decision-makers in the water management sector at various scales, ranging from irrigation districts to river basin management.

Mediterranean crops, such as almond crops, are adapted to long and dry summers with high temperatures and no rain, which greatly limit agricultural productivity in those climates [33]; irrigation provides an adaptation to this seasonal aridity. The system increases productivity when supplementary or full irrigation is applied, especially since the mild and wet winters allow adapted crops to maximise the use of soil water in winter and spring before climatic conditions become adverse. Almond cultivation is well adapted to the Mediterranean climate. It is considered a drought-tolerant crop because it exhibits xeromorphic characteristics [34,35]. The analysis conducted here is valid for southern Spain with a precipitation in the range of 400 to $600 \mathrm{~mm}$; in these conditions, the crop can partly take advantage of the soil water derived from seasonal rain.

The adaptation to deficit irrigation as shown by the case study in Andalusia (southern Spain) is not possible for all crops and all circumstances and depends upon the economic conditions (fixed and variable costs, and crop price), and the functional production form $y(w)$.

The application of the model described in this paper to the production function obtained by Goldhamer and Fereres [14] in Kern County (southern California) fails to provide a real solution for Equation (10). In Kern County, almonds are grown in extreme arid conditions (average rainfall of $118 \mathrm{~mm}$ ), and the low precipitation leads to the need for higher water doses than those in the southern Spain case (average rainfall of $590 \mathrm{~mm}$ ). This is illustrated by the fact that maximum yield is found in southern California for an irrigation dose of approximately $1250 \mathrm{~mm}$ compared to $975 \mathrm{~mm}$ in the Spanish case. In California, the almond industry is currently subject to criticism that was initiated during the last drought (2011-2017), in which growers were forced to reduce water use by $25 \%$ [36]. Full irrigation aimed at maximising yield remains the generalized strategy. According to Goldhamer and Fereres [14], the productivity at economic optimum in California (around $1100 \mathrm{~m}$ ) entails an average water productivity of $0.32 \mathrm{~kg} / \mathrm{m}^{3}$.

In Australia (second greatest almond producer worldwide after California), the strategic approach to almond irrigation is similar to that in California and involves the application of full irrigation to achieve maximum production. A report published on the almond orchards in Victoria state $(334 \mathrm{~mm}$ average rainfall) suggests either the application of full irrigation or the application of a limited deficit (85\% of full irrigation dose) to guarantee minimal yield impact [37]. This strategy produces productivity ranging from $0.19 \mathrm{~kg} / \mathrm{m}^{3}$ (full irrigation) to $0.22 \mathrm{~kg} / \mathrm{m}^{3}$ (deficit irrigation).

Administrative conditions in Spain regarding water rights are more severe regarding water use since water is a public resource and the assignment of water rights are subject to hydrological basin plans. The average water rights for farmers in Andalucía are close to $3200 \mathrm{~m}^{3} / \mathrm{ha}$ [38], although many farmers apply 6000 to $7000 \mathrm{~m}^{3} /$ ha to their almond orchards when they either attain access to water entitlements of a more generous nature or they manage this by internal in-farm reallocation (by leaving a portion of the farm to be rainfed). Consequently, various public administrations 
encourage a deficit-irrigation strategy, as is the case of the regional governments of Andalusia [39] and Extremadura [27]. This approach increases the average productivity of irrigation water from $0.27 \mathrm{~kg} / \mathrm{m}^{3}$ reached in the maximum yield solution (with an irrigation dose of $975 \mathrm{~mm}$ ) to $0.52 \mathrm{~kg} / \mathrm{m}^{3}$ in the optimum deficit irrigation $(251 \mathrm{~mm})$.

Obviously, when water is not a limiting production factor and the farmer has sufficient water rights per hectare, as is the case in California (where the average irrigation use across the state is $11,000 \mathrm{~m}^{3} /$ ha [14]), irrigated land constitutes the limiting factor and rational behaviour to maximise profit implies a solution close to the maximum yield with a productivity of irrigation water in the environ of $0.22 \mathrm{~kg} / \mathrm{m}^{3}$, as shown by the case of Australia, or of $0.32 \mathrm{~kg} / \mathrm{m}^{3}$ in the case of California. However, when water is limited, a strategy such as that proposed herein increases the irrigation water productivity and overall farm profits. California water governance is currently under drastic change following the new legislation through the Sustainable Groundwater Management Act, which has been introduced as a response to the severe impacts of the latest long drought (2011-2017) [24].

The consequences at the microeconomic scale result in a greater economic value of water and greater profits at the farm level. Specifically, this work shows how farmers might be maximising the return to water, thereby considering that water acts as a limiting production factor and that land acts as a variable, instead of the traditionally considered maximum return to land, which considers the economic optimum with water as the variable input and land as the limiting production factor. This behaviour is consistent in those locations (or river basins) where water resources are depleted and constitute a limiting factor for agricultural production.

When the results of the microeconomic model of individual farmer decision-making are aggregated at the regional scale, then the general adoption of a deficit-irrigation strategy implies an increase in regional agricultural output, thereby maximising the global return to water. In Andalusia, the irrigated area covers $27 \%$ of total cultivated area and the demand for water has reached a limit since there are no more available resources and the different basins in Andalusia have reached a "closed" status [25]. However, the increased productivity of water triggers additional pressures on water use, as illustrated in the case of olive irrigation in the Guadalquivir river basin.

The findings of this study show that deficit irrigation is a strategy for the adaptation to water scarcity that farmers may use in the context of limited water supply in order to maximise farm profits. Deficit-irrigation strategies are also employed to achieve a more sustainable use of water in those areas with water scarcity $[40,41]$. Regional governments may promote the implementation of deficit-irrigation techniques with the aim of maximising regional farm value when water is the limiting production factor. The model used here is a first approximation, and strategies of reducing fixed costs by means of either lowering the density of tree plantation or by simplifying irrigation systems may lower fixed costs and increase the area irrigated, thereby increasing water productivity. Tree plantation density in terms of trees per hectare in the experimental design used herein as the basis for our model ranges from 214 (California) to 238 (Spain) and to 296 (Australia). Tree plantation densities may well vary when the application of deficit irrigation is decided before planting, since it implies lowering the densities which in turn leads to a revised production function that takes into consideration said lower densities. Furthermore, kernel size has not been considered in our model, and therefore, future developments should also take kernel size into consideration in the optimisation model.

Finally, future research should consider the potential effects of this strategy on the resiliency of the systems and of the consequences of this behaviour at the river basin level by taking other factors into account, such as $\mathrm{CO}_{2}$ capture, quantity and quality of return flows, and any other relevant environmental or social variables.

Author Contributions: Both authors have contributed equally to the research design, development, and the writing of the manuscript. Both authors have read and agreed to the published version of the manuscript.

Funding: This research was funded by Junta de Andalucía, research group WEARE (SEJ 592).

Conflicts of Interest: The authors declare there to be no conflict of interest. 


\section{References}

1. Stewart, J.I.; Hagan, R.M. Functions to predict effects of crop water deficits. J. Irrig. Drain Div. ASCE 1973, 99, 421-439.

2. Vaux, H.; Pruitt, W.O. Crop-Water Production Functions. In Advances in Irrigation; Elsevier BV: Amsterdam, The Netherlands, 1983; pp. 61-97.

3. Battese, G.E. Frontier production functions and technical efficiency: A survey of empirical applications in agricultural economics. Agric. Econ. 1992, 7, 185-208. [CrossRef]

4. Howitt, R.; MacEwan, D.; Medellin-Azura, J.; Lund, J.; Sumner, D. Economic Analysis of the 2015 Drought for California Agriculture; University of California, Davis Center for Watershed Sciences, Agricultural Issues Center: Davis, CA, USA, 2015.

5. Moriana, A.; Orgaz, F.; Pastor, M.; Fereres, E. Yield Responses of a Mature Olive Orchard to Water Deficits. J. Am. Soc. Hortic. Sci. 2003, 128, 425-431. [CrossRef]

6. Mesa-Jurado, M.A.; Berbel, J.; Orgaz, F. Estimating marginal value of water for irrigated olive grove with the production function method. Span. J. Agric. Res. 2010, 8, 197. [CrossRef]

7. Expósito, A.; Berbel, J. Microeconomics of Deficit Irrigation and Subjective Water Response Function for Intensive Olive Groves. Water 2016, 8, 254. [CrossRef]

8. Goldhamer, D.A.; Viveros, M. Effects of preharvest cutoff durations and postharvest water deprivation on almond tree perfor- mance. Irrig. Sci. 2000, 19, 125-131. [CrossRef]

9. Goldhamer, D.A.; Viveros, M.; Salinas, M. Regulated deficit irrigation in almonds: Effects of variations in applied water and stress timing on yield and yield components. Irrig. Sci. 2005, 24, 101-114. [CrossRef]

10. Esparza, G.; DeJong, T.M.; Weinbaum, S.A.; Klein, I. Effects of irrigation deprivation during the harvest period on yield determinants in mature almond trees. Tree Physiol. 2001, 21, 1073-1079. [CrossRef]

11. Girona, J.; Mata, M.; Marsal, J. Regulated deficit irrigation during the kernel-filling period and optimal irrigation rates in almond. Agric. Water Manag. 2005, 75, 152-167. [CrossRef]

12. Egea, G.; Nortes, P.; González-Real, M.M.; Baille, A.; Domingo, R. Agronomic response, and water productivity of almond trees under contrasted deficit irrigation regimes. Agric. Water Manag. 2010, 97, 171-181. [CrossRef]

13. Stevens, R.M.; Ewenz, C.M.; Grigson, G.; Conner, S.M. Water use by an irrigated almond orchard. Irrig. Sci. 2011, 30, 189-200. [CrossRef]

14. Goldhamer, D.A.; Fereres, E. Establishing an almond water production function for California using long-term yield response to variable irrigation. Irrig. Sci. 2016, 35, 169-179. [CrossRef]

15. López, M.L.; Espadafor, M.; Testi, L.; Lorite, I.J.; Orgaz, F.; Fereres, E. Yield response of almond trees to transpiration deficits. Irrig. Sci. 2018, 36, 111-120. [CrossRef]

16. English, M. Deficit Irrigation. I: Analytical Framework. J. Irrig. Drain. Eng. 1990, 116, 399-412. [CrossRef]

17. Berbel, J.; Mateos, L. Does investment in irrigation technology necessarily generate rebound effects? A simulation analysis based on an agro-economic model. Agric. Syst. 2014, 128, 25-34. [CrossRef]

18. Doorenbos, J.; Kassam, A. Yield Response to Water. Irrig. Agric. Dev. 1980, 33, 257-280. [CrossRef]

19. Steduto, P.; Hsiao, T.C.; Raes, D.; Fereres, E. Crop Yield Response to Water; Food and Agriculture Organization of the United Nations: Rome, Italy, 2012.

20. Dagnino, M.; Ward, F.A. Economics of Agricultural Water Conservation: Empirical Analysis and Policy Implications. Int. J. Water Resour. Dev. 2012, 28, 577-600. [CrossRef]

21. International Nut and Dried Fruit. Statistical Yearbook 2019/2020; INC: Reus, Spain, 2020; Available online: https://www.nutfruit.org/industry/technical-resources?category=statistical-yearbooks (accessed on 2 February 2020).

22. Ministry of Agriculture, Fishing and Food (MAPA). Anuario de Estadística; Ministerio de Agricultura, Pesca y Alimentación: Madrid, Spain, 2018; Available online: https:/www.mapa.gob.es/es/estadistica/temas/ publicaciones/anuario-de-estadistica/ (accessed on 1 April 2020).

23. Fereres, E.; Soriano, M.A. Deficit irrigation for reducing agricultural water use. J. Exp. Bot. 2006, 58, 147-159. [CrossRef]

24. Berbel, J.; Esteban, E. Droughts as a catalyst for water policy change. Analysis of Spain, Australia (MDB), and California. Glob. Environ. Chang. 2019, 58, 101969. [CrossRef]

25. Expósito, A.; Berbel, J. Agricultural Irrigation Water Use in a Closed Basin and the Impacts on Water Productivity: The Case of the Guadalquivir River Basin (Southern Spain). Water 2017, 9, 136. [CrossRef] 
26. García, J.G.; Romero, P.; Botía, P.; García, F. Análisis económico del cultivo de almendro en riego deficitario controlado (RDC). Fruticul. Prof. 2005, 154, 43-50.

27. Diario Oficial de Gobierno de Extremadura [Regional Government of Extremadura]. Costes De La Futura Zona Regable Tierra de Barros, Extremadura; Gobierno de Extremadura: Extremadura, Spain, 2014.

28. Novello, R. Costes Operativos del Almendro; II Jornada Tecnica del Almendro: Caspe, Spain, 2019.

29. Ministry of Environment (MIMAN). Precios y Costes de los Servicios del Agua en España; Ministerio de Medioambiente: Madrid, Spain, 2007.

30. Ministry of Agriculture, Fishing and Food (MAPA). Jornada de Frutos Secos: Caracterización del Sector; Ministerio de Agricultura, Pesca y Alimentación: Valencia, Spain, 2019.

31. Molden, D.; Oweis, T.; Steduto, P.; Bindraban, P.; Hanjra, M.A.; Kijne, J. Improving agricultural water productivity: Between optimism and caution. Agric. Water Manag. 2010, 97, 528-535. [CrossRef]

32. English, M.; Raja, S.N. Perspectives on deficit irrigation. Agric. Water Manag. 1996, 32, 1-14. [CrossRef]

33. Jacobsen, S.-E.; Jensen, C.; Liu, F. Improving crop production in the arid Mediterranean climate. Field Crop. Res. 2012, 128, 34-47. [CrossRef]

34. Romero, P.; Navarro, J.M.; García, F.; Ordaz, P.B. Effects of regulated deficit irrigation during the pre-harvest period on gas exchange, leaf development and crop yield of mature almond trees. Tree Physiol. 2004, 24, 303-312. [CrossRef]

35. Torrecillas, A.; Alarcón, J.; Domingo, R.; Planes, J.; Sánchez-Blanco, M. Strategies for drought resistance in leaves of two almond cultivars. Plant Sci. 1996, 118, 135-143. [CrossRef]

36. Megerian, C.; Stevens, M.; Boxall, B. Brown Orders California's First Mandatory Water Restrictions: It is a Different World; Los Angeles Times: Los Angeles, LA, USA, 2015.

37. Monks, D.; Taylor, C.; Sommer, K.; Treeby, M. Deficit irrigation of almond trees did not decrease yield. Acta Hortic. 2017, 1150, 251-260. [CrossRef]

38. Confederación Hidrográfica del Guadalquivir (CHG). Plan Hidrológico de la Demarcación del Guadalquivir 2015-2021, R. D. 1/2016; Confederación Hidrográfica del Guadalquivir: Sevilla, Spain, 2016.

39. Proyecto GRUP SAT. El Cultivo Moderno del Almendro en España. Available online: https://www. juntadeandalucia.es/export/drupaljda/resumen_estudio_viabilidad_almendro.pdf (accessed on 1 April 2020).

40. Expósito, A.; Berbel, J. Sustainability Implications of Deficit Irrigation in a Mature Water Economy: A Case Study in Southern Spain. Sustainability 2017, 9, 1144. [CrossRef]

41. Abdelkhalik, A.; Pascual-Seva, N.; Nájera, I.; Baixauli, C.; Seva, P.-; Pascual-Seva, N. Deficit Irrigation as a Sustainable Practice in Improving Irrigation Water Use Efficiency in Cauliflower under Mediterranean Conditions. Agronomy 2019, 9, 732. [CrossRef] 